\title{
Perceptual Errors in Chinese language Processing: A Case Study of CZeCH LeARNers
}

\author{
Tereza SLAMĚNÍKOVÁ \\ Palacký University Olomouc, Czech Republic \\ tereza.slamenikova@upol.cz
}

\begin{abstract}
There are now a vast number of cross-linguistic studies that investigate how perceptual performance with non-native speech categories is constrained by the listener's native language. However, considering the acquisition of the Chinese language phonological system, studies examining the transfer from less frequent languages are rather rare. The aim of this paper is to fill the gap regarding Czech native speakers. Through examining errors in dictation tests, it introduces some difficulties experienced by beginner level Chinese students and thus provides insight on the perception of Chinese language segmental and suprasegmental features by Czech learners. The findings imply that while errors in initials and finals show a high influence of the native language, errors in disyllabic tonal combinations seem to follow the basic language-independent patterns that have been observed in previous studies.
\end{abstract}

Keywords: second-language acquisition; non-native speech perception; L1 interference; Chinese phonological system; Czech learners

\section{Povzetek}

Obstajajo številne raziskave o tem, kako na zaznavanje govornih kategorij vpliva slušateljev materni jezik, vendar pa so raziskave o usvajanju kitajskega fonološkega sistema s stališča manjših jezikov še vedno zelo maloštevilne. Namen te raziskave je torej zapolniti vrzel z rezultati čeških maternih govorcev. S proučitvijo njihovih napak v narekih avtor predstavi pogoste težave, ki jih imajo češki študenti kitajščine na začetnem nivoju, in ponudi vpogled $v$ značilnosti njihovega zaznavanja na segmentnem in prozodičnem nivoju. Ugotovitve kažejo, da medtem ko so napake v soglasniški začetnici zloga (angl. initial) oz. končniškemu sklopu zloga (angl. final) posledica negativnega vpliva maternega jezika, napake $v$ dvozložnih tonskih kombinacijah sledijo ustaljenim vzorcem in so neodvisne od maternega jezika slušatelja.

Ključne besede: usvajanje drugega/tujega jezika; zaznavanje govora drugega/tujega govora; vplivi maternega jezika; kitajski glasovni sistem; češki študentje

Acta Linguistica Asiatica, 7(1), 2017.

ISSN: 2232-3317, http://revije.ff.uni-lj.si/ala/

DOI: 10.4312/ala.6.2.89-101 


\section{Introduction}

At the beginning of this research, the aim was to optimize the content of a course introducing the Chinese phonological system to first-year students in the Chinese Philology B.A. program at Palacký University in Olomouc. Although the characteristics of the Chinese phonological system have been thoroughly described, taking into account its differences from Czech phonological properties (Švarný, 1998; Švarný \& Uher, 2001; Trísková, 2014), Chinese teaching materials were used in the course due to the absence of any set of practical exercises. Despite the fact that this material provides a comprehensive training program, the teaching experience has shown that it did not fully meet the requirements of the specific native speaker group. In particular, it does not seem to sufficiently emphasize the similarities and differences between the Chinese and Czech phonological features.

It is generally recognized that a speaker's native language (L1) experience significantly impacts many aspects of second language (L2) acquisition. The influence of the native phonological system on the production and perception of $L 2$ speech sounds is no exception. L2 learners tend to transmit phonological rules from their native language, as well as implement strategies used in L1 acquisition. Using Trubetzkoy's (1969) famous metaphor, the native language phonological system represents a sieve "through which everything that is said is processed" (p. 51). When a learner hears another language, his linguistic experience sets the parameters that constrain perception of the L2 phonological system.

As for Chinese language ${ }^{1}$ acquisition, the rapidly growing interest in studying Chinese is bringing increasing attention to its pedagogical theory and practice. Nevertheless, case studies reporting difficulties caused by L1 linguistic experience are still limited to just a few languages. Even though teaching Chinese in the Czech Republic already has an 80-year tradition, there is no systematic study investigating Czechspecific influences on Chinese language processing.

The linguistically homogeneous environment of the Czech Republic ${ }^{2}$ provides a space for the adaptation of learning paths according to the needs of a specific group of learners. In order to adjust the course called Introduction to Chinese Phonetics to meet the needs of Czech learners, different investigations were carried out, obtaining complex insights. Among other things, an analysis of dictation tests has been performed. These dictation tests have been used as a tool for testing students' perception skills at the end of the course for the last 15 years. As such, they provide a

\footnotetext{
${ }^{1}$ The term Chinese used in this paper refers to Modern Standard Chinese, with pronunciation based on the Beijing dialect.

${ }^{2}$ Strictly speaking, the needs of two specific groups of learners are taken into account, since Slovak students are also enrolled in the Chinese philology program at Palacký University. Nevertheless, the vast majority of students are of Czech origin. For this study, the target group is only Czech learners.
} 
valuable data collection source whose analysis can reveal useful information on Chinese language processing. By examining the errors occurring in dictation tests, this paper attempts to fill a gap in our understanding of Czech students' Chinese language perception. After a brief introduction of the course's organization and the structure of the dictation test, errors at the segmental and suprasegmental level will be investigated.

\section{Organization of the course}

Introduction to Chinese Phonetics is a mandatory course taken by all Chinese Philology students in the first semester of their study. ${ }^{3}$ Its aim is to introduce students to the basic speech features of Chinese, laying the groundwork for successful language learning. Using the official romanization system Pinyin, students' ability to produce and perceive speech sounds is being systematically developed. 21 45-minute lessons are scheduled three times a week. Different types of exercises are used to improve students' listening ability and production accuracy. After seven weeks of intensive training, students take a dictation test covering both segmental and suprasegmental phonological levels, i.e. the range of Chinese initials and finals, as well as four lexical tones in their 15 possible disyllabic tonal combinations.

The Chinese handbook Hanyu Putonghua Yuyin Bianzheng 《汉语普通话语音辨 正》 'Correction of Standard Chinese Pronunciation' is used as the main teaching material; however, it has been adapted for the purposes of the course. Using a discreteitem approach, the first third of the course focuses on initials, the second on finals and the last on tonal combinations. Initials and finals with similar phonological features (place or manner of articulation) are compared and drilled. The training is applied with disyllabic compounds as basic units of the modern Chinese lexicon. While practicing a specific feature (e.g. finals -an and -ang), either two syllables within the same compound (e.g. dāngrán), or two compounds are contrasted (e.g. kāifàn vs. kāifàng) .

It must be mentioned that the Introduction to Chinese Phonetics course is just one part of a comprehensive curriculum in the Chinese philology program; listening and oral comprehension skills are developed in different courses. The goal of this course is to help learners achieve familiarity with common phonemes of the Chinese language as soon as possible. Disyllabic compounds are used as a tool to achieve this goal, regardless of their lexical meaning, in order to restrict learners' concentration to acoustic language features. Considering the non-tonal background, basic

\footnotetext{
${ }^{3}$ Warm thanks are due to Professor David Uher, PhD, who as a course supervisor and author of the dictation test kindly supported the idea to analyze errors in order to prepare more effective study materials.
} 
suprasegmental units are introduced as well. Sentence-level prosodic patterns are practiced in the follow up courses during the second, third and fourth semesters.

\section{Dictation tests}

The dictation test contains 100 disyllabic compounds altogether. They are chosen from the exercises used during the course, and no additional combinations are included. Each compound is dictated twice by the teacher and the entire duration of the test is approximately 20 minutes. A special form is used, which is divided into four parts as shown below. It is composed of three partial dictation tasks and one full dictation task. In the first part (numbers 1 to 25), finals are preprinted and students are supposed to fill in the initials according to the dictation. In the second part (numbers 26 to 50) it is the other way around: initials are preprinted and finals (without tones) are to be written down. The third part (numbers 51 to 75) focuses on tonal combinations: students have to mark tones above syllables. These three parts are intended as warmup exercises that should help students gather their concentration for the most difficult task: in the last part of the test (numbers 76 to 100) they are expected to note down the entire disyllabic compound including tone marks. Since the second and last part require more time for writing, they are dictated at a slower speed. Below is an example of a filled-out test form.

\begin{tabular}{|c|c|c|c|c|c|c|c|c|c|c|c|c|c|}
\hline 01 & $\ell$ & ái & $r$ & i & 26 & b & an & $\mathbf{z h}$ & any & 51 & pingdeng & 76 & buintón \\
\hline 02 & ch & ú & 9 & ù & 27 & $t$ & ing & $\mathbf{x}$ & in & 52 & houguó & 77 & nüpú \\
\hline 03 & $\checkmark$ & ù & $x$ & iě & 28 & $\mathbf{b}$ & en & $\mathrm{n}$ & eng & 53 & dōngfēng & 78 & twier \\
\hline 04 & i & ià & zh & i & 29 & $y$ & in & $\mathbf{x}$ & in $y$ & 54 & jiéjué & 79 & tiānrán \\
\hline 05 & i & $\overline{\mathbf{u}}$ & g & ān & 30 & $\mathbf{h}$ & an & $t$ & ong & 55 & jinyú & 80 & $y \bar{n} n i^{\prime}$ \\
\hline 06 & ch & $\overline{\mathbf{a}}$ & $c$ & uò & 31 & $\mathrm{f}$ & an & $\mathrm{m}$ & ande & 56 & lianxu & 81 & bai \\
\hline 07 & $E$ & è & $d$ & ì & 32 & $j$ & nom & $\mathbf{x}$ & ian & 57 & hâjūn & 82 & $\sqrt{h}$ \\
\hline 08 & sh & ăo & $x$ & uั & 33 & $q$ & ing & $\mathbf{x}$ & in & 58 & gàobié & 83 & \\
\hline 09 & $z$ & $i$ & zh & uàn & 34 & $t$ & $4 i$ & $\mathbf{x}$ & iw & 59 & tígāng & 84 & \\
\hline 10 & $r$ & è & $l$ & iè & 35 & $r$ & en & ch & eng & 60 & gudal $i$ & 85 & \\
\hline 11 & $p$ & ù & $b$ & ù & 36 & $\mathbf{z}$ & ang & 1 & aw & 61 & huänying & 86 & \\
\hline 12 & $z$ & á & $j$ & $i$ & 37 & $\mathbf{x}$ & lanty & q & ian & 62 & qilchuáng & 87 & \\
\hline 13 & $x$ & ùn & $s$ & ù & 38 & $j$ & in & $q$ & ing & 63 & páiduì & 88 & \\
\hline 14 & $f$ & ù & $h$ & è & 39 & d & uaw & $\mathbf{z h}$ & waing & 64 & huácáo & 89 & \\
\hline 15 & c & $\bar{a}$ n & ch & $\overline{\mathrm{e}}$ & 40 & w & 4 & $\mathbf{y}$ & ans & 65 & dîdiăn & 90 & man \\
\hline 16 & sh & $\overline{\mathrm{u}}$ & $S$ & àn & 41 & sh & eng & $x$ & en & 66 & $y^{\text {innyue }}$ & 91 & shi \\
\hline 17 & $d$ & ài & $E$ & i & 42 & $y$ & ad & $j$ & iw & 67 & yinman & 92 & \\
\hline 18 & $b$ & $\bar{i}$ & $p$ & ò & 43 & 1 & ian & $\mathrm{q}$ & unn & 68 & shưgēn, & 93 & \\
\hline 19 & 9 & $\overline{\mathrm{u}}$ & ch & ú & 44 & $\mathbf{x}$ & in & $y$ & ing & 69 & yichuan & 94 & liv \\
\hline 20 & $x$ & iāo & sh & òu & 45 & sh & ang & sh & ant & 70 & tudis & 95 & wing \\
\hline 21 & $z h$ & $i$ & $z$ & uò & 46 & $j$ & lan & $\mathrm{q}$ & iang & 71 & sangshi & 96 & \\
\hline 22 & $g$ & ăn & $k$ & ăi & 47 & d & any & $\mathrm{f}$ & eng & 72 & yanchu & 97 & lièwëi \\
\hline 23 & s & ù & Sh & è & 48 & d & ong & $\mathbf{s}$ & un & 73 & bùdulे & 98 & zongezhaing, \\
\hline 24 & h & ào & I & èi & 49 & d & ing & $q$ & in & 74 & lianhuān & 99 & xiáché \\
\hline 25 & $z h$ & á & $i$ & $i$ & 50 & $\mathrm{ch}$ & en & $\mathbf{k}$ & en & 75 & yunxing & 100 & dōngxîn \\
\hline
\end{tabular}

Figure 1: The filled-in dictation test form 


\section{Procedure}

This study does not attempt to meet the requirements of experimental research. Tests were designed for the purpose of assessing students at the end of the course, not to provide a venue for research. Based on theoretical knowledge about listening comprehension and the teaching experience, the tests were designed in order to measure listening skills gained during the course. Even though the operationalization process applied while compiling an assessment test (theoretical notions about the nature of the listening construct were turned into actual practice, in a set of test items) is similar to that at beginning of the experimental research procedure, the parameters used in compiling the test were determined by its primary purpose, which was not to observe but to assess students' performance. Nevertheless, the tests represent a valuable data source, especially considering the amount of collected materials and the long time span when they were collected. As such, they provide an otherwise not easily obtainable source for exploring perceptual errors by Czech learners of Chinese. The specific circumstances regarding the data collection, however, have to be taken into account while interpreting the findings.

The dictations have been held since 2002 and up to now over 1500 tests have been collected. This paper investigates errors occurring in the tests from 2002 to 2008 . There were altogether 715 tests collected during this period. The first examination of the tests has, however, shown that those with a high error rate need to be excluded from the analysis. The majority of errors clearly indicated a lack of familiarity with the notation system, i.e. letters used to write down initials and finals were highly influenced by the symbols used in Czech orthography. This fact made it difficult to identify perceptual difficulties. Due to this, tests with a maximum of 10 errors were selected in order to analyze speech perception at the segmental level ( $27 \%$ of the analyzed sample). Considering the fact that no interference with the Czech graphic system can be expected while placing the tonal marks, the analyzed sample was extended to 20 errors at the suprasegmental level (52\% of the analyzed sample).

During this time, many different versions of tests were used. Although the general layout has not changed, the set of disyllabic compounds used vary from one to another. Because the tests were constructed with the intention of providing a general testing tool, the features of the Chinese phonological system are not equally distributed. As such, they were not suitable for the analysis of sensitivity to specific speech contrasts in the form of scores on correct identifications. Considering this fact, tests were analyzed in terms of errors in initials, finals and tonal combinations. The incorrect notations for each of these three units were collected together in order to identify the underlying patterns. 


\section{Results}

Errors were evaluated from two perspectives. Firstly, disyllabic compounds with incorrectly noted initials and finals were examined. Secondly, confusions in tonal combinations were analyzed. Analysis of tests with a maximum of 10 errors has shown that proportionally speaking, Czech students experience more difficulties with the acquisition of the segmental level than with the perception of the disyllabic tonal combinations. Nonetheless, it has to be noticed that the vast majority of errors at the segmental level consist of errors in finals. In fact, errors in both finals and tonal combinations each account for about two fifths of incorrectly noted compounds. Contrary to expectations that a wider spectrum of errors might occur within the fourth (full dictation) part of the test, the analysis did not reveal significant differences. Besides, considering the long time period of data collection, the results imply only a negligible variation of errors typology. Thus, the overall findings are presented in the following two subsections.

\subsection{Errors at the segmental level}

Analysis has shown that errors in initials occur rarely. The results do not exactly support the presumption that because of the different distinctive phonological features characteristic for Czech (correlation of voicing) and Chinese (correlation of aspiration), Czech students might have difficulties with distinguishing aspirated and non-aspirated consonants (Trísková, 2014). Only one of the six pairs, velars $g$ - and $k-,{ }^{4}$ appeared multiple times within incorrectly noted initials. The familiarity of the non-aspirated voiceless consonants obviously represents a solid basis for the aspirated consonant recognition.

However, distinguishing aspirated consonants from one other, specifically the dental $c$ - and post-alveolar $c h$ - versus palatal $q$-, cause Czech students the biggest difficulties. Apparently students tend to overlook the fact that $c$ - and $c h$ - combine with a completely different set of finals than $q$-. As can be seen below, the incorrectly noted versions are either pronounced completely differently or do not even exist. More than anything else, these errors mostly indicate a lack of familiarity with the Chinese phonological system. However, one cannot overlook the possible reason for these confusions. Affricates $c$ - and $c h$ - before apical vowels are pronounced differently than in combination with other vowels: the type of aspiration is the same as in case of affricate $q$ - (Třísková, 2012, p. 143) which might be a similarity causing confusion.

Besides, the analysis has shown that students tend to overlook the different distributional environments of the fricatives $x$ - and sh-as well. It must be the same

\footnotetext{
${ }^{4}$ Considering the topic of this paper, Pinyin letters are used to note the described initials and finals.
} 
place of articulation that tempts students to fail to notice not just their complementary distribution, but also their phonological differences. Nevertheless, in contrast to another pair of errors these are easily fixed. The palatals $q$ - and $x$ - share the same set of finals, and since neither of them is present in the Czech phonological inventory they are quite difficult to master.

Table 1: Most frequent errors in initials

\begin{tabular}{||l|l|}
\hline Initials & Examples \\
\hline k- vs. g- & chāngguáng instead of chāngkuáng \\
\hline c-/ch- vs. q- & $\begin{array}{l}\text { cìchuán instead of qìchuán } \\
\text { qāoqún instead of chāoqún }\end{array}$ \\
\hline sh- vs. $x$ - & xīnxăng instead of xīnshāng \\
\hline q- vs. $x$ - & yuánqiān instead of yuánxiān \\
\hline
\end{tabular}

Four fifths of errors on the segmental level consisted of incorrectly noted finals. Three features causing difficulties can be identified. Two of them are related to single finals. Firstly, about $10 \%$ of errors show difficulties with the distinction between midround -e and the two apical vowels - $i$ after post-alveolars $z h-, c h-, s h-, r$ - and dentals $z-$ , c-, s-. Secondly, about $16 \%$ of errors involve front high vowels, specifically discriminating between unrounded $-i$ and rounded $-\ddot{u}$. Students mostly tend to miss the higher level of roundedness than the other way around. Both of these types of errors are explainable in terms of differences between the Czech and Chinese vowel systems.

However, the most difficult finals to perceive are those with nasal endings, which appear in more than two thirds of the incorrectly noted finals. Even though both alveolar and velar nasals can be found in Czech speech sounds, the velar nasal is just a positional variant of the alveolar phoneme and is regularly used before velar consonants $k$ - or $g$ - in the middle of words. In comparison with Chinese, the alveolar and velar nasal do not occur in contrastive distribution. The experience of Czech learners with velar nasals is limited to a certain environment, which must be a reason why its mastery is difficult. Trísková (2012, p. 290) points out that under the influence of their native language, Czech students tend to put non-aspirated velar $k$ - after the velar nasal while pronouncing the velar nasal. As far as our own pedagogical experience is concerned, they also tend to merge velar nasals with alveolar nasals, making no distinction between them. Analysis of dictation has shown the same blending in their perception. The recognition of differences between the two types of nasal endings has been identified as the most difficult issue of speech perception. Considering the structure of the final, the following pairs are especially difficult to distinguish: -in vs. -ing, -uan vs. -uang and -an vs. -ang. 
Errors in finals with nasal endings are not limited to those relating to discrimination of nasals. There were also difficulties with vowel differentiation before velar nasals. Firstly, confusion of final -ang and -eng was identified. Secondly, a syllable with zero initial ying was repeatedly noted incorrectly as yong or yung. It seems difficult for students to distinguish the nucleus of finals whose pronunciation is affected by the velar nasal ending. Besides, there was one syllable with alveolar ending that, based on a spectrum of incorrect notation, can be marked as difficult to perceive as well. It is the final $-u(\partial) n$, and as shown below, the incorrect notations of the example syllable sun include suan, sang and song.

Table 2: Most frequent errors in finals

\begin{tabular}{||l|l||}
\hline Finals & Examples \\
\hline \hline apical vowels -i vs. back unrounded -e & bōzhí instead of bōzhé \\
\hline unrounded front high -i vs. rounded -ü & lüjī instead of lüjū \\
\hline $\begin{array}{l}\text { alveolar vs. velar nasals } \\
\text { (-in/-ing, -uan/-uang, -an/-ang) }\end{array}$ & $\begin{array}{l}\text { jīnxīn instead of jīngxīn } \\
\text { chāngkuán instead of chāngkuáng } \\
\text { shēngchăng instead of shēngchăn }\end{array}$ \\
\hline finals -ang vs. -eng & píngdăng instead of píngděng \\
\hline syllable ying & incorrectly noted as yong, yun, yung \\
\hline final -un (-uen) & $\begin{array}{l}\text { dōngsuăn, dōngsăng, dōngsǒng instead } \\
\text { of dōngsǔn }\end{array}$ \\
\hline
\end{tabular}

To sum up, confusion on the segmental level appears to be proportional to the dissimilarities between both languages in phonetic and phonological features. They reveal in substantial measure the main differences in the phonological organization of Czech and Chinese. In regard to the experience gained through teaching the Introduction to Chinese Phonetics course, one cannot overlook the correspondence with the most prominent pronunciation difficulties, confirming a high level of correlation between speech production and perception.

Considering the types of errors, they appear to be consistent with the fundamental premise of the so-called perceptual assimilation model of cross-language speech perception described by C. T. Best (1995). She pointed out that the reason L2 learners discern the differences between pairs of sounds in the L2 might be the fact that they tend to perceive the non-native sounds "according to their similarities to, and discrepancies from, the native constellations that are in the closest proximity to them in native phonological space" (p. 185).

Within the above described errors, several examples can be found indicating that learners show a tendency to assimilate non-native sounds to the most similar native 
category that is straightforwardly closest in the L1 phonological space. This must be the reason why Czech learners have difficulties with distinguishing $k-v s . g-, x-v s$. sh-, $-\ddot{u}$ vs. $-i$ and velar vs. alveolar finals: it is due to assimilation, non-native sounds and the closest native sounds being perceived as members of the same category. On the other hand, it also seems that non-native palatals $q$ - and $x$-are not strongly assimilated to two different native categories since learners also face difficulties with their differentiation. These errors might indicate another type of assimilation defined by Best, i.e. uncategorizable speech sounds that are assimilated within native phonological space but not as a clear example of any particular native category. This also seems to be case of another pair of non-native speech sounds: apical vowels $-i$ and back round vowel $-e$.

\subsection{Errors at the suprasegmental level}

Within the analyzed sample of dictation tests, 778 incorrectly noted tonal combinations were collected. According to occurrence of errors, the 15 possible tonal combinations 5 can be divided into the following four levels of difficulty. As can be seen, there is at least a $1 \%$ gap between neighboring levels.

Table 3: Errors in tones

\begin{tabular}{|c|c|c|}
\hline Level & Percentage of errors in tones & Combinations \\
\hline \hline 1. & over $13 \%$ & $\mathrm{~T} 3-\mathrm{T} 4, \mathrm{~T} 1-\mathrm{T} 3$ \\
\hline 2. & $11 \%-9 \%$ & $\mathrm{~T} 2-\mathrm{T} 4, \mathrm{~T} 2-\mathrm{T} 1, \mathrm{~T} 2-\mathrm{T} 3, \mathrm{~T} 4-\mathrm{T} 3$ \\
\hline 3. & $7 \%-4 \%$ & $\mathrm{~T} 3-\mathrm{T} 1, \mathrm{~T} 4-\mathrm{T} 2, \mathrm{~T} 1-\mathrm{T} 2, \mathrm{~T} 3-\mathrm{T} 2$ \\
\hline 4. & less than $2 \%$ & $\mathrm{~T} 4-\mathrm{T} 1, \mathrm{~T} 1-\mathrm{T} 4, \mathrm{~T} 4-\mathrm{T} 4, \mathrm{~T} 1-\mathrm{T} 1, \mathrm{~T} 2-\mathrm{T} 2$ \\
\hline
\end{tabular}

The results indicate that the easiest tonal combinations to recognize are all combinations of the two same tones. Besides, the combinations of T1 and T4, regardless of their position, also belong to the least difficult group of tonal combinations. On the other hand, the combinations with T2 or T3 (including their mutual combinations) appear to be not easy to perceive. The most difficult combination is T3-T4: its incorrect notations account for $19 \%$ of errors in tonal combinations. Taken together with T1-T3 as the second most difficult combination, their incorrect notations constitute almost one third of all errors at the suprasegmental level.

\footnotetext{
${ }^{5}$ T3-T3 was included under T2-T3 because its pronunciation is, due to the sandhi rule, the same.
} 
Let us now examine types of errors in detail. Firstly, the position of the error within the combination was investigated. Analysis has revealed that students have more difficulties to recognize the tone on the first syllable than on the second syllable. To be specific, $69 \%$ errors occur on the initial and $37 \%$ on the final syllable. It seems that the impression of the second syllable might influence the perception of the first one. As the numbers indicate, errors on both syllables are rather rare; this was the case in only $6 \%$ of incorrectly noted combinations.

Secondly, the question to be answered is whether the errors show any systematic behavior. Analysis has pointed out some important results that need to be further discussed. First of all, a strong connection between errors occurring within combinations T3-T4 and T2-T4 has been identified. As for the T2-T4, it is T3 that can be found on the first syllable in almost of $90 \%$ of its incorrect notations. And vice versa the same phenomenon can be observed, even though with a slightly lower frequency rate: T2 occurs on the first syllable in the $82 \%$ of incorrectly noted T3-T4 combinations. It appears that T4 starting at the top of pitch range makes it difficult for students to distinguish whether the preceding syllable was rising or not.

Moreover, the same connection can be identified for another pair of combinations. As for T1-T2 and T1-T3, Czech students face perceptual confusion between T2 and T3 on the second syllable. In this case, the mutual error frequency rate of $64 \%$ is identical for both combinations.

Nonetheless, patterns without such a clear mutual connection can be observed as well. Considering the other combinations rated above as most difficult, three other easily misidentified pairs of combinations can be identified. As can be seen below in Fig. 4, the error rate frequency for T2-T3 incorrectly noted as T4-T3 is especially high. However, errors concerning the combination T4-T3 occur more often with the second syllable being confused for $\mathrm{T} 2$.

Table 4: Tonal combinations: most frequent types of errors

\begin{tabular}{|c|c|c||}
\hline Combination & Incorrectly noted as & Rate \\
\hline \hline T2-T4 & T3-T4 & $90 \%$ \\
\hline T3-T4 & T2-T4 & $82 \%$ \\
\hline T2-T3 & T4-T3 & $84 \%$ \\
\hline T1-T2 & T1-T3 & $64 \%$ \\
\hline T1-T3 & T1-T2 & $64 \%$ \\
\hline T4-T3 & T4-T2 & $51 \%$ \\
\hline T4-T3 & T2-T3 & $36 \%$ \\
\hline
\end{tabular}


The results demonstrate that the greatest difficulties in tonal differentiation involve the pair of T2 and T3. Considering the fact that students take the test after seven weeks of training, this result is consistent with McGinnis's (1996, p. 87) theory that at the second stage of development of tonal perception skills, students begin to develop tonal confusion difficulties on the basis of similar tonal contours. However, it has been also observed that Czech learners experience difficulties concerning T2 and T4 discrimination, which are, according to McGinnis's research relating to American English speakers, easy to confuse during the initial period of Chinese language study because learners place greater emphasis on the extreme endpoint of a given tone and less on its direction.

Generally speaking, phonetic features of tones are considered one of the key factors that have been found to affect tone learning. Gandour (1981) has observed that tones which are highly similar in their Fundamental Frequency (FO) are more likely to be confused than tones whose FO patterns are different. His findings were later confirmed in several other studies. In one recent study, So \& Best (2010) examined the tonal perception of six Chinese syllables by Hong Kong Cantonese, Japanese and Canadian American native speakers. Although their results revealed language-specific errors, language independent patterns were identified as well: regardless of the learners' backgrounds, tones which have similar phonetic features (T1 vs. T2, T2 vs. T3, T1 vs. T4) were more difficult to distinguish than those with dissimilar features (T1 vs. T3, T2 vs. T4, T3 vs. T4). As for the Czech students, difficulties with the discrimination of $\mathrm{T} 2$ and $\mathrm{T} 3^{6}$ are consistent with this theory. It also aligns with the general assumption that $\mathrm{T} 2$ and $\mathrm{T} 3$ are the most confusable tone pair.

However, significant differences can be found when comparing the results with another recent study, this time focusing on disyllabic compounds. Lilienfeld (2015) examined tone perception by 111 beginner level Chinese students from different backgrounds (tonal as well as non-tonal, though none of them was from a Slaviclanguage background). Despite certain mean score differences, all students performed similarly for overall tonal combination perception. Analyzing the results, Lilienfeld detected the impact of tone placement as one of the factors influencing the perception of T3; the combinations with T3 on the initial position (T3-T1, T3-T2 and T3-T4) were identified as hardest, in contrast to the easiest tonal combinations T1-T3 and T2-T3. These findings are considerably different from those identified in the case of Czech learners. Only the combination T3-T4 was found to be the most difficult in both studies. Otherwise, the results of this study are the opposite of those obtained by Lilienfeld. Combinations T1-T2 and T2-T3 belong to those that were highly misinterpreted; on the other hand, errors within combinations T3-T1 and T3-T2 appear to be relatively

\footnotetext{
${ }^{6}$ The similarity shared by $\mathrm{T} 2$ and $\mathrm{T} 3$ is that both have a lower-to-higher pitch range, even though for $\mathrm{T} 3$ this is the case only in the final position.
} 
fewer. Unfortunately, Lilienfeld's study does not include any description of error patterns typical for each combination, whose comparison might provide additional insight.

Despite the obvious differences, there is one important fact connecting both Lilienfeld's and the present study. Although all the most frequent errors are in some way connected with $\mathrm{T} 3$, the results suggest that one cannot sum it up as an overall difficulty regardless of the tonal combination. However, compared to Lilienfield's findings, it is obvious that the perception difficulties with $\mathrm{T} 3$ observed in Czech students show a more complex pattern. Firstly, difficulties with discrimination of T3 and T2 on the initial syllable occur in disyllabic compounds with T4 on the final syllable. Secondly, $\mathrm{T} 3$ and $\mathrm{T} 2$ on the final syllable are not easy to distinguish in disyllabic compounds with T1 or T4 on the initial syllable. Moreover, the position of T3 on the final syllable makes the recognition of $\mathrm{T} 2$ and $\mathrm{T} 4 \mathrm{~m}$ on the initial syllable difficult.

\section{Conclusion}

The analysis of errors occurring in dictation tests has revealed how Czech listeners' performance is constrained by their phonological system. The results demonstrate that, despite their non-tonal language background, the discrimination of tonal combinations is not the most challenging issue in Chinese speech perception for Czech learners, or at least not after the intensive seven weeks of training that the students went through before taking the test. If anything, they seem to experience the same difficulties with perception of Chinese finals as well. Besides, the study has also provided an overview of the most confusable pairs at the segmental and suprasegmental level. Unlike the language-specific errors in initials and finals, the identified patterns of errors in tonal combinations appear to be language-independent, since they are, in general, consistent with what has been reported in previous studies on cross-linguistic perception of the Standard Chinese tonal system, i.e. that tones with similar features are likely to cause more perceptual difficulties. In addition, the findings have also indicated that the tone errors of Czech learners seem to follow relatively complex patterns.

\section{References}

Best, C. T. (1995). A direct realist view of cross-language speech perception. In W. Strange (Ed.), Speech perception and linguistic experience: Issues in cross-language research (pp. 171204). Baltimore: York Press.

Buck, G. (2001). Assessing listening. Cambridge: Cambridge University Press.

Duanmu, S. (2007). The phonology of Standard Chinese. New York: Oxford University Press. 
Gandour, J. (1981). Perceptual dimensions of tone: Evidence from Cantonese. Journal of Chinese Linguistics, 9(1), 20-36.

Gottfried, T. L., \& Suiter, T. L. (1997). Effect of linguistic experience on the identification of Mandarin tone identification. Journal of Phonetics, 25(2), 207-231.

Lee, Y.-S., Vakoch, D. A., \& Wurm, L. H. (1996). Tone perception in Cantonese and Mandarin: A cross-linguistic comparison. Journal of Psycholinguistic Research, 25(5), 527-542.

Li, M. [李明] \& Shi, P. [石佩雯]. (1998). Hanyu Putonghua Yuyin Bianzheng 《汉语普通话语音 辨正》. Beijing: Beijing Yuyan Xueyuan Chubanshe.

Lilienfeld, B. (2015). A mixed method study of Mandarin tone perception, production and selfregulated strategy use (Doctoral dissertation).

Lin Y.-H. (2007). The sounds of Chinese. Cambridge: Cambridge University Press.

McGinnis, S. (1996). Tonal distinction errors by beginning Chinese language students: A comparative study of American English and Japanese native speakers. In S. McGinnis (Ed.), Chinese pedagogy: An emerging field (pp. 81-91). Columbus: Ohio State University.

Palková, Z. (1994). Fonetika a fonologie češtiny. Praha: Univerzita Karlova.

So, C. K., \& Best, C. (2010). Cross-language perception of non-native tonal contrasts: effects of native phonological and phonetic influences. Language and Speech, 53(2), 273-293.

Švarný, O., \& Uher, D. (2001). Hovorová čínština. Úvod do studia hovorové čínštiny. Olomouc: Univerzita Palackého v Olomouci.

Švarný, O., et al. (1988). Hovorová čínština v př́kladech. Olomouc: Vydavatelství Univerzity Palackého.

Trubetzkoy, N. (1969). Principles of phonology. Berkeley: University of California Press.

Třísková, H. (2012). Segmentální struktura čínské slabiky. Praha: Karolinum.

Třísková, H. (2014). Aspirované souhlásky v čínštině a v angličtině. Časopis pro moderní filologii, 94(2), 196-218. 